\title{
SENSORY EVALUATION OF PLIEK-U QUALITY USING FUZZY-TOPSIS METHOD
}

\author{
Raida AGUSTINA*, MUSTAQIMAH, Rahmat FADHIL, DEVIANTI \\ Universitas Syiah Kuala, Indonesia
}

\begin{abstract}
The purpose of this study is to apply one of the decision-making methods, namely the fuzzy-TOPSIS method, to determine the best alternative of coconut fermentation in process of making Pliek-U, which is a typical powder made of coconut and is used for traditional cooking recipes by people in Aceh Province, Indonesia. The weight of fuzzy criteria and judgments about alternative methods of coconut fermentation was used to calculate the sensory evaluation scores and Pliek-U quality ratings. It can help to determine the quality of the Pliek-U. Sensory evaluation results for the quality of Pliek-U using the fuzzy-TOPSIS method showed that the most ideal alternative of the coconut fermentation method in the process of making Pliek-U is the 10-day coconut fermentation method, because it had the highest closeness coefficient (0.7484) in contrast to the 7-day coconut fermentation method (0.5425), and 4-day coconut fermentation method (0.3291). The fuzzy-TOPSIS method utilization was beneficial for generating the sensory multi-criteria assessment calculations through weighting, so that the process of determining consumer acceptance of the product assessed became easier and faster.
\end{abstract}

Keywords: coconut; fermentation; quality rating; respondent; hedonic scale

There are three derivative products made of processed coconut, i.e. Pliek-U, Simplah oil, or fermented virgin coconut oil (FVCO) (Khathir et al., 2020), and Pliek oil. Processing of Pliek- $U$ requires several essential stages, namely the fermentation stage, and then the oil is separated after several days of fermentation. The next stage includes drying and pressing with hydraulic pressure (Agustina and Munawar, 2019). Pliek-U produced by conventional fermentation processes has a slightly acidic taste, smells rancid, is moldy, and of dark color (Rohaya et al., 2019). The improvement of Pliek-U fermentation method by several alternative fermentation techniques is expected to increase the quality and quantity of Pliek-U (Mustaqimah et al., 2019).

Sirangelo (2019) explained that sensory evaluation can be done objectively or subjectively. In many cases, the available data is sometimes inadequate for issues in real life, because human judgments, including preferences, are often vague or unclear and preferences cannot be estimated with an appropriate numerical value. Therefore, a fast method of evaluating consumer acceptance of food products is needed. One method of evaluating the respondents' opinions is the fuzzy-TOPSIS (Technique for Order Performance by Similarity to Ideal Solution) method, in which the respondents evaluate each product and provide an assessment of the product acceptance level based on multi-sensory criteria including aroma, colour, taste, and texture (Fadhil et al., 2019).

\section{Fuzzy-TOPSIS method}

Many methods are used in ranking and choosing the alternative solutions to solve problems in decision making that are influenced by multi-criteria (Tulkhah and Saifuddin, 2019). One method commonly used for multicriteria decision-making techniques (Multiple Attribute Decision Making MADM) is the fuzzy-TOPSIS method, which was first introduced by Yoon (1980), Hwang and Yoon (1981), Yoon and Kim (2017). Furthermore, this method has been used by Rouhani et al. (2012), Fadhil et al. (2017a), Fadhil et al. (2017b), Shindu et al. (2019), Fadhil et al. (2019), Yazdi et al. (2020), and Rouyendegh et al. (2020). Fuzzy-TOPSIS method can help in evaluating of various alternatives of various criteria that are considered, including in determining the right method to produce high-quality food products based on sensory evaluation. In the fuzzy-TOPSIS approach, the alternative selection is based on the value of closeness to the value of a positive ideal solution (FPIS), and on the furthest value from the value of a negative ideal solution (FNIS) (Papilo et al., 2018). According to Fadhil et al. (2019), TOPSIS can only be implemented for criteria, weights of which are known or calculated beforehand, because there is a stage in TOPSIS involving the multiplication process of criteria weights and alternative values on a criterion.

The purpose of this study is to apply the fuzzy-TOPSIS decision-making technique in determining the best alternative for the selection of coconut fermentation methods in the process of making Pliek-U. Results of the fuzzy-TOPSIS method analysis are expected to be used as information or recommendations to help farmers or business producers in determining the best alternative for coconut fermentation in making Pliek-U. 


\section{Material and methods}

This research was conducted at the Post Harvest Technology Laboratory of Agricultural Engineering Study Program, Agriculture Faculty, Universitas Syiah Kuala, in June 2019. The material used in this study was coconut meat that was rasped. The tools used included digital scale meters, thermometers, dryers, and hydraulic type press tools.

\section{Research stages}

This research was divided into two main stages. The first stage was the Pliek-U fermentation process with a combination of thick pile treatment and fermentation time. The second stage was conducting a multi-criteria sensory assessment of Pliek-U through the collection of respondents/ panellists' opinions.

\section{Framework}

The determination of weighting of respondents' assessment criteria for multi-criteria in the Pliek-U sensory evaluation was done by a hedonic scale, which can also be changed to a numerical scale with number quality according to the preference level. The respondent's hedonic scale included aroma, colour, and taste of Simplah oil, Pliek oil, and Pliek-U. Chauhan and Sharma (2003) mentioned that sensory assessments utilizing human senses, such as aroma, colour, and taste, are the most influential judgments on the acceptance of a product based on the decisions of respondents/panellists. The detailed explanation of each of these criteria is shown in Table 1, while the Pliek-U sensory preference values based on the hedonic scale are presented in Table 2. An assessment of each alternative by respondents using the fuzzy-TOPSIS method with preference values is given in Table 3 .

Table 1 Pliek-U sensory multi-criteria assessment criteria

\begin{tabular}{|l||c|}
\hline Criteria & Assessment considerations \\
\hline Colour of simplah Oil (C1) & limpid, clear \\
\hline Aroma of simplah Oil (C2) & the aroma is rather pungent \\
\hline Colour of pliek oil (C3) & yellowish limpid, clear \\
\hline Aroma of pliek oil (C4) & typical aroma of coconut oil \\
\hline Colour of pliek-U (C5) & brownish \\
\hline Aroma of pliek-U (C6) & typical aroma of coconut, not rancid and rather acidic \\
\hline Taste of pliek-U (C7) & acidic \\
\hline
\end{tabular}

Table 2 Pliek-U sensory assessment preferences based on hedonic scale

\begin{tabular}{|l|c|}
\hline Value & Preference \\
\hline $\mathbf{5}$ & really like \\
\hline $\mathbf{4}$ & like \\
\hline $\mathbf{3}$ & neutral \\
\hline $\mathbf{2}$ & dislike \\
\hline $\mathbf{1}$ & wery dislike \\
\hline
\end{tabular}

Table 3 Comparison of alternative determination scale of fuzzy-TOPSIS method

\begin{tabular}{|l||c|}
\hline Scale & TFN linguistic \\
\hline \hline Very dislike (VD) & $1,1,2$ \\
\hline Dislike (D) & $1,2,3$ \\
\hline Neutral (N) & $2,3,4$ \\
\hline Like (L) & $3,4,5$, \\
\hline Really like (RL) & $4,5,5$ \\
\hline
\end{tabular}

The framework of this research was construed in four steps, namely:

1. the aim was set as sensory evaluation of Pliek-U;

2. the analysis was done through determining the weight of assessment criteria and determining alternative decisions;

3. alternative determination methods using fuzzy-TOPSIS were carried out;

4. alternative ranking decisions were obtained as results.

\section{Respondent selection}

Ten respondents were selected to conduct a sensory multi-literacy assessment of Pliek-U with various types of treatment. The selection of respondents was determined by using a number of criteria - whether they are fond of Pliek- $U$, whether they prefere to consume it either raw or in the form of processed products, whether they are experienced in sensory testing, whether they show any sign of illness (such as colds, cough, canker sores, etc.) - which may interfere the sensory testing process, whether they are not colour-blind, etc.

These criteria were used because sensory evaluation is very dependent on humans who will accurately express their sensory experiences of a product (Hamilton and Jacob, 2020). Lawless and Heymann (2010) also mentioned that sensory evaluation consists of a series of ways to measure human responses to food, which minimize the effects that have the potential to cause bias on the characteristics and identity of a product, as well as the influence of other information on consumer perception.

\section{Fuzzy-TOPSIS procedure}

The fuzzy-TOPSIS method used in this study was carried out by weighing the criteria with a Triangular Fuzzy Number (TFN) value; in such manner, the criteria are more objective (Pochampally et al., 2004). This was because the data from the respondents' preferences that were available were inadequate to solve the problem of the Pliek-U fermentation method, because the human judgment of preferences is often influenced by subjectivity, so the results are vague or unclear and cannot determine the preference values with appropriate numerical values. 


\section{Steps of the fuzzy-TOPSIS method}

Halicka (2020) mentioned steps in the application of the fuzzy-TOPSIS method, i.e.:

1. Choosing the right linguistic variable with the importance criteria $\left(\widetilde{W}_{i}=l_{i j}, m_{i j}, u_{i j}\right)$ and alternative linguistic ranking of the criteria $\left(\tilde{x}_{i j}\right)$ in TFN.

2. Aggregating the weights from each criterion to get fuzzy weight aggregates $\left(\widetilde{W}_{j}\right)$ on the criteria $C_{j}$ and determining the fuzzy aggregate weight of the alternative $A_{i}$ on each criterion $C_{j}$ :

$$
\tilde{x}_{i j}=\frac{1}{k}\left[\tilde{x}_{i j}^{1}+\tilde{x}_{i j}^{2}+\ldots+\tilde{x}_{i j}^{k}\right]
$$

$i=1,2 \ldots, m ; j=1,2 \ldots, n$

$$
w_{j}=\frac{1}{k}\left[\tilde{w}_{j}^{1}+\tilde{w}_{j}^{2}+\ldots+w_{j}^{k}\right]
$$

$j=1,2 \ldots, n$

3. Building a normalized decision matrix. Pochampally et al. (2004) mentioned this step to change the size of various dimensions of performance into non-dimensional attributes. The $r_{i j}$ element resulted from the normalization of the decision matrix $R$ with the Euclidean length of a vector method as follows:

$$
r_{i j}=\frac{x_{i j}}{\sqrt{\sum_{i=1}^{m} x_{i j}^{2}}}
$$

with $i=1,2,3 \ldots, m ; j=1,2,3 \ldots, n$

4. Building the weighted normalized decision matrix.

Positive ideal solution $A^{+}$and negative ideal solution $A^{-}$can be determined based on the normalized weight rating $\left(y_{i j}\right)$ as:

$$
y_{i j}=w_{i} r_{i j}
$$

with $i=1,2,3 \ldots, m ; j=1,2,3 \ldots, n$

5. Determining a positive ideal solution matrix and a negative ideal solution matrix. Positive ideal solution $\left(A^{+}\right)$is calculated based on:

$$
S^{+}=\left(y_{1}^{+}, y_{2}^{+}, y_{3}^{+} \ldots \ldots \ldots y_{n}^{+}\right)
$$

Negative ideal solution $A^{-}$is calculated based on:

$$
S^{-}=\left(y_{1}^{-}, y_{2}^{-}, y_{3}^{-} \ldots \ldots \ldots y_{n}^{-}\right)
$$

6. Calculating the distance between each alternative value with the value of FPIS (Fuzzy Positive Ideal Solution) and FNIS (Fuzzy Negative Ideal Solution):

$$
D_{1}^{+}=\sqrt{\sum_{i=1}^{n}\left(y_{i j}-y_{i}^{+}\right)^{2}}
$$

$i=1,2,3 \ldots, m$

$$
D_{1}^{-}=\sqrt{\sum_{i=1}^{n}\left(y_{i j}-y_{i}^{-}\right)^{2}}
$$

$i=1,2,3 \ldots, m$

7. Determining the preference value for each alternative. The closeness of each alternative to the ideal solution is calculated based on the formula:

$$
C C_{i}=\frac{D_{i}^{-}}{D_{i}^{+}+D_{i}^{-}}
$$

$i=1,2,3 \ldots, m$

8. Ranking the alternative.

After the preference value for each alternative was determined, alternatives were ranked according to the $C C_{i}$ value (Boran et al., 2009). The alternative with the largest $C C_{i}$ value represented the best solution.

\section{Results and discussion}

The alternative determination was conducted by following the fuzzy-TOPSIS method through the decomposition of the analysis results into 6 stages. The best alternative was selected based on the highest closeness coefficient to each alternative compared.

\section{Stage 1}

Input data were collected via sensory questionnaires with a hedonic scale that were arranged into a comparison matrix (Table 4).

Table 4 Respondents' assessment matrix on various alternative methods of coconut fermentation

\begin{tabular}{|l|c||c|c|c|}
\hline \multicolumn{2}{|c||}{ Criteria } & \multicolumn{3}{c|}{ Fermentation alternatives } \\
\cline { 3 - 5 } & 4 days & 7 days & 10 days \\
\hline \hline \multirow{3}{*}{ Simplah Oil } & colour (C1) & 5 & 5 & 5 \\
\cline { 2 - 5 } & aroma (C2) & 4 & 3 & 4 \\
\hline \multirow{3}{*}{ Pliek Oil } & colour (C3) & 3 & 4 & 4 \\
\cline { 2 - 5 } & aroma (C4) & 4 & 3 & 3 \\
\hline \multirow{3}{*}{ Pliek-U } & colour (C5) & 5 & 5 & 4 \\
\cline { 2 - 5 } & aroma (C6) & 3 & 3 & 4 \\
\cline { 2 - 5 } & taste (C7) & 3 & 4 & 4 \\
\hline
\end{tabular}

Sensory evaluation can be used as an instrument to control the quality of a product, because the people's acceptance or preference represented by respondents is one of the keys to the success of marketing the product (Popov-Raljic and Lalicic-Petronijevic, 2009; Ana et al., 2017). Consumers often judge the initial quality of a product by its colour and appearance, because this is the main indicator 
when assessing the product quality, especially food. Colour also correlates with changes in aroma and taste (Lawless and Heymann, 2010). For Simplah oil colour, all respondents gave a value of 5 (really like). For Pliek-U oil and Pliek-U colour, respondents gave a value of 4 (like) for 10-day fermentation.

For the aroma of Simplah oil, respondents gave a rating of 4 (like) for 10-day fermentation. For the aroma of Pliek oil, respondents gave a value of 4 (like) for 4-day fermentation, because it was typical of coconut oil and not rancid. The longer the fermentation time, the higher the free fatty acids content in Pliek oil. According to Umudee et al. (2013), the percentage of free fatty acids is the most important parameter for assessing the quality of vegetable oils, such as copra oil, the content of free fatty acids of which can increase by $1,410 \%$ during fermentation to a range of $0.660-2.502 \%$. One way to reduce the free fatty acids in oil is by using microwave heating (Vieira and Regitano-D'Arce, 1998; Khathir et al., 2020). Application of metal-organic frameworks enhances the physicochemical properties of unrefined vegetable oils (more pleasant taste and odour), because free fatty acids and peroxide compounds are bound in such manner (Hlaváč et al., 2019). For the aroma of Pliek-U, respondents gave a value of 4 (like) for10-day fermentation, because Pliek-U showed typical aroma of coconut, which was neither rancid, nor acidic.

For the taste of Pliek-U, respondents gave a value of 4 (like) for 10-day fermentation, because its taste was more acidic than in case of 4-day fermentation. Based on research of Mustaqimah et al. (2019), the $\mathrm{pH}$ value of the 10-day fermented Pliek-U was 5.0, while that of 4-day and 7-day fermentation were 5.8 and 5.1 , respectively. Therefore, it can be concluded that the longer the fermentation period,

Table 5 Respondent's assessment matrix of alternative fermentation methods on the TFN scale

\begin{tabular}{|c|c|c|c|c|c|c|c|c|c|c|}
\hline \multirow{2}{*}{\multicolumn{2}{|c|}{ Criteria }} & \multicolumn{3}{|c|}{ 4-day fermentation } & \multicolumn{3}{|c|}{ 7-day fermentation } & \multicolumn{3}{|c|}{ 10-day fermentation } \\
\hline & & lower & middle & upper & lower & middle & upper & lower & middle & upper \\
\hline \multirow{2}{*}{ Simplah oil } & colour (C1) & 4 & 5 & 5 & 4 & 5 & 5 & 4 & 5 & 6 \\
\hline & aroma (C2) & 3 & 4 & 5 & 2 & 3 & 4 & 3 & 4 & 5 \\
\hline \multirow{2}{*}{ Pliek oil } & colour (C3) & 2 & 3 & 4 & 3 & 4 & 5 & 3 & 4 & 5 \\
\hline & aroma (C4) & 3 & 4 & 5 & 2 & 3 & 4 & 2 & 3 & 4 \\
\hline \multirow{3}{*}{ Pliek-U } & colour (C5) & 4 & 5 & 5 & 4 & 5 & 5 & 3 & 4 & 5 \\
\hline & aroma (C6) & 2 & 3 & 4 & 2 & 3 & 4 & 3 & 4 & 5 \\
\hline & taste $(C 7)$ & 2 & 3 & 4 & 3 & 4 & 5 & 3 & 4 & 5 \\
\hline
\end{tabular}

Table 6 Matrix multiplication of weighting criteria and alternative normalization values

\begin{tabular}{|c|c|c|c|c|c|c|c|c|c|c|}
\hline \multicolumn{2}{|l|}{ Criteria } & \multicolumn{3}{|c|}{ 4-day fermentation } & \multicolumn{3}{|c|}{ 7-day fermentation } & \multicolumn{3}{|c|}{ 10-day fermentation } \\
\hline & & $\mathbf{I}$ & m & $\mathbf{u}$ & $\mathbf{I}$ & m & $\mathbf{U}$ & $\mathbf{I}$ & $\mathbf{m}$ & $\mathbf{u}$ \\
\hline \multirow{2}{*}{ Simplah oil } & colour (C1) & 1.33 & 2.50 & 3.33 & 1.33 & 2.50 & 3.33 & 1.33 & 2.50 & 4.00 \\
\hline & aroma (C2) & 1.80 & 2.40 & 3.00 & 1.20 & 2.40 & 4.00 & 1.80 & 3.20 & 5.00 \\
\hline \multirow{2}{*}{ Pliek oil } & colour (C3) & 0.80 & 1.80 & 3.20 & 1.20 & 2.40 & 4.00 & 1.20 & 2.40 & 4.00 \\
\hline & aroma (C4) & 1.80 & 3.20 & 5.00 & 1.20 & 2.40 & 4.00 & 1.20 & 2.40 & 4.00 \\
\hline \multirow{3}{*}{ Pliek-U } & colour (C5) & 1.60 & 3.00 & 4.00 & 1.60 & 3.00 & 4.00 & 1.20 & 2.40 & 4.00 \\
\hline & aroma (C6) & 1.20 & 2.40 & 4.00 & 1.20 & 2.40 & 4.00 & 1.80 & 3.20 & 5.00 \\
\hline & taste $(\mathrm{C} 7)$ & 1.60 & 3.00 & 4.00 & 2.40 & 4.00 & 5.00 & 2.40 & 4.00 & 5.00 \\
\hline
\end{tabular}

Table $7 \quad$ Value of positive and negative ideal solutions

\begin{tabular}{|l|c||c|c|}
\hline \multicolumn{2}{|l||}{ Criteria } & \multicolumn{1}{c|}{$\boldsymbol{S}^{+}$} & \multicolumn{1}{c|}{$\boldsymbol{S}$} \\
\hline \multirow{3}{*}{ Simplah oil } & colour (C1) & $(1.33,2.50,4.00)$ & $(1.33,2.50,4.00)$ \\
\hline \multirow{3}{*}{ Pliek oil } & aroma (C2) & $(1.80,3.20,5.00)$ & $(1.20,2.40,3.00)$ \\
\hline \multirow{3}{*}{ Pliek-U } & colour (C3) & $(1.20,2.40,4.00)$ & $(0.80,1.80,3.20)$ \\
\cline { 2 - 3 } & aroma (C4) & $(1.80,3.20,5.00)$ & $(1.20,2.40,4.00)$ \\
\cline { 2 - 4 } & colour (C5) & $(1.60,3.00,4.00)$ & $(1.20,2.40,4.00)$ \\
\cline { 2 - 3 } & aroma (C6) & $(1.80,3.20,5.00)$ & $(1.20,2.40,4.00)$ \\
\cline { 2 - 3 } & taste (C7) & $(2.40,4.00,5.00)$ & $(1.60,3.00,4.00)$ \\
\hline
\end{tabular}


the lower the $\mathrm{pH}$ value. This is in line with the statement of Khathir et al. (2018), who stated that the fermentation process tends to increase the acidic taste, which is characterized by a decrease in $\mathrm{pH}$ value.

\section{Stage 2}

The next step to determine the alternative priorities for the coconut fermentation method was to collect the preferences of respondents' choices, which were translated into lower, middle, and upper boundary values. After compiling a matrix of respondents' evaluation of various alternative methods of coconut fermentation (Table 4), the respondents' evaluation data were then converted into TFN linguistic data (Table 5).

\section{Stage 3}

The next step was to aggregate the TFN value into weighting interests and normalizing of weighting interests. Furthermore, a multiplication matrix between the criteria weight and normalization value of each alternative fermentation method was arranged (Table 6).

\section{Stage 4}

The next step was to determine the value of the positive ideal solution (FPIS) $S^{+}$and the value of the negative ideal solution (FNIS) S (Table 7).

\section{Stage 5}

The next stage was to calculate the value of distance between each alternative value with the value of a positive ideal solution and the value of a negative ideal solution. The results of these calculations are given in Table 8.

Based on the comparison of $d^{+}$and $d^{-}$conducted to evaluate the value of the criteria distance with Fuzzy Positive Ideal Solution (FPIS) and Fuzzy Negative Ideal Solution (FNIS), a radar diagram (Fig. 1) was plotted - it shows the

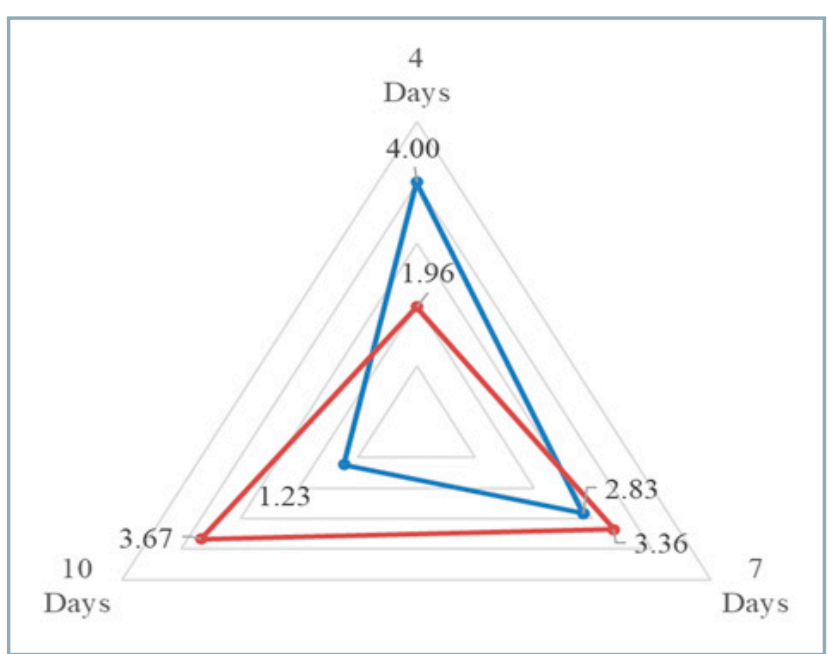

Fig. 1 Evaluation of $d^{+}$and $d$

product acceptance preferences. It is obvious that the 7-day fermentation treatment showed the $d^{+}$and $d^{-}$values with the smallest distance from the positive and negative ideals, while the 10-day fermentation treatment showed the $d^{+}$and $d^{\top}$ values with the greatest distance from the positive and negative ideals.

Dashti et al. (2010) explained that the principle used in the TOPSIS method is that the chosen alternative must have the shortest distance from the positive ideal solution and the farthest from the negative ideal solution to determine the relative closeness of an alternative to the optimal solution.

\section{Stage 6}

The last step was to calculate the value of relative closeness preference to the ideal solution (closeness coefficient $-C_{i}$ ) of each alternative (Table 9).

Table 8 Value of the distance between the criteria value with FPIS and FNIS

\begin{tabular}{|c|c|c|c|c|c|c|c|}
\hline \multicolumn{2}{|l|}{ Criteria } & \multicolumn{3}{|c|}{ FPIS $\left(d^{+}\right)$} & \multicolumn{3}{|c|}{ FNIS $\left(d^{-}\right)$} \\
\hline & & \multirow{2}{*}{$\begin{array}{c}4 \text { days } \\
0.38\end{array}$} & \multirow{2}{*}{$\begin{array}{c}7 \text { days } \\
0.38\end{array}$} & \multirow{2}{*}{$\begin{array}{c}10 \text { days } \\
0.00\end{array}$} & \multirow{2}{*}{$\begin{array}{c}4 \text { days } \\
0.38\end{array}$} & \multirow{2}{*}{$\begin{array}{c}7 \text { days } \\
0.38\end{array}$} & \multirow{2}{*}{$\begin{array}{c}10 \text { days } \\
0.00\end{array}$} \\
\hline Simnlah oil & colour (C1) & & & & & & \\
\hline "1" & aroma (C2) & 1.24 & 0.82 & 0.00 & 0.35 & 1.00 & 1.29 \\
\hline \multirow{2}{*}{ Pliek oil } & colour (C3) & 0.62 & 0.00 & 0.00 & 0.00 & 0.62 & 0.62 \\
\hline & aroma (C4) & 0.00 & 0.82 & 0.82 & 0.82 & 0.00 & 0.00 \\
\hline \multirow{3}{*}{ Pliek-U } & colour (C5) & 0.00 & 0.00 & 0.42 & 0.42 & 0.42 & 0.00 \\
\hline & aroma (C6) & 0.82 & 0.82 & 0.00 & 0.00 & 0.00 & 0.82 \\
\hline & taste $(C 7)$ & 0.94 & 0.00 & 0.00 & 0.00 & 0.94 & 0.94 \\
\hline \multicolumn{2}{|l|}{$d^{+}$and $d^{-}$} & 4.00 & 2.83 & 1.23 & 1.96 & 3.36 & 3.67 \\
\hline
\end{tabular}

Table 9 Closeness and alternative ranking coefficients

\begin{tabular}{|c|c|c|c|}
\hline & \multicolumn{3}{|c|}{ Fermentation alternatives } \\
\hline & 4 days & 7 days & 10 days \\
\hline$C C_{i}$ & 0.3291 & 0.5425 & 0.7484 \\
\hline Ranking & 3 & 2 & 1 \\
\hline
\end{tabular}


Based on the calculation results of relative closeness preference value of each alternative in Table 9, it appears that the10-day fermentation method had the greatest value of 0.7484 . The alternative fermentation method, which has the largest coefficient value, is the main alternative that is recommended to be selected or prioritized compared to other alternatives based on the preferences of the respondents' choices (product acceptance). Based on the value of the closeness coefficient $\left(C C_{i}\right)$, an alternative ranking method of fermentation can be formed, arranging the fermentation methods from the largest to the smallest $\mathrm{CC}_{i}$ value:

1. 10-day coconut fermentation,

2. 7-day coconut fermentation,

3. 4-day coconut fermentation.

The 10-day alternative fermentation method had the shortest or closest distance to the positive ideal solution 1.23 , and the distance to the farthest negative ideal solution was 3.67. Fuzzy-TOPSIS method is based on the concept of using multi-criteria decision-making methods or alternative choices, which are alternatives that have the shortest distance from the positive ideal solution and the longest distance from the negative ideal solution. According to Pochampally et al. (2004), the best alternative is determined based on ranking preference on the value of closeness coefficient $\left(C C_{i}\right)$.

Based on the analysis of results using the fuzzy-TOPSIS approach in the aforementioned steps, 10-day coconut fermentation method is the main and ideal according to the preferences of respondents from among the observed alternative methods of coconut fermentation.

\section{Conclusion}

Sensory evaluation analysis of Pliek-U quality using the fuzzy-TOPSIS method was able to find the most ideal or prime alternative of coconut fermentation treatment from the 3 alternatives considered. Based on the fuzzy-TOPSIS method approach, the highest closeness coefficient value 0.7484 was obtained by the 10-day coconut fermentation alternative. Furthermore, the quality of Pliek-U produced using 10-day fermentation treatment showed a higher level of product acceptance than the quality of Pliek-U produced using 4-day and 7-day coconut fermentation treatments. Ultimately, respondents also preferred Simplah oil, Pliek oil, and Pliek-U produced utilizing the 10-day fermentation treatment.

\section{Acknowledgement}

This work was supported by Universitas Syiah Kuala, the Ministry of Education and Culture, Republic of Indonesia, Penelitian Lektor No. 270/UN11/SPK/PNBP/2020.

\section{References}

AGUSTINA, R. - MUNAWAR, A. A. 2019. Electro-optic properties of dried Pliek-U powder: local ingredients from Aceh. In IOP Conference Series: Earth and Environmental Sciences, vol. 365.
BORAN, E. - GENÇ, S. - KURT, M. - AKAY, D. 2009. A multi-criteria intuitionistic fuzzy group decision making for supplier selection with topsis method. In Expert Systems with Applications, vol. 36, no. 8, pp. 11363-11368.

DASHTI, Z. - PEDRAM, M. M. - SHANBEHZADEH, J. 2010. A multicriteria decision making based method for ranking sequential patterns. In Proceedings of International Multi-Conference of Engineers and Computer Scientist, Hongkong, vol. 1.

FADHIL, R. - MAARIF, M. S. - BANTACUT, T. - HERMAWAN, A. 2017a, Multi criteria decision support system for the development of Gayo coffee agroindustry using fuzzy-eckenrode and fuzzy-topsis approaches. In Jurnal Teknologi Industri Pertanian, vol. 27, no. 1, pp. 103-113. (In Indonesian: Sistem penunjang keputusan multi kriteria untuk pengembangan agroindustri kopi gayo menggunakan pendekatan fuzzy-eckenrode dan fuzzy-topsis).

FADHIL, R. - MAARIF, M. S. - BANTACUT, T. - HERMAWAN, A. 2017b. Comparison of multi-criteria decision making techniques between the eckenrode method and the fuzzy eckenrode method on agroindustry performance. In Jurnal Manajemen \& Agribisnis, vol. 14, no. 2, pp. 109-117. (In Indonesian: Perbandingan teknik pengambilan keputusan multi-kriteria antara metode eckenrode dengan metode fuzzy eckenrode pada kinerja agroindustri).

FADHIL, R. - AGUSTINA, R. - MUSTAQIMAH. 2019. A multi-criteria sensory assessment of curcumis melo L. using fuzzy-eckenrode and fuzzy-topsis methods. In Journal Foods and Raw Materials, vol. 7, no. 2, pp. 339-347.

HALICKA, K. 2020. Technology selection using the topsis method. In Foresight and STI Governance, vol. 14, no. 1, pp. 85-96.

HAMILTON, M. L. - JACOB, L. 2020. Fast and automated sensory analysis: using natural language processing for descriptive lexicon development. In Food Quality and Preference, vol. 83.

HLAVÁČ, P. - BOŽIKOVÁ, M. - PETROVIC, A. 2019. Selected physical properties assessment of sunflower and olive oils. In Acta Technologica Agriculturae, vol. 22, no. 3, pp. 86-91.

HWANG, C. L. - YOON, K. 1981. Multiple Attributes Decision Making Methods and Applications. Springer, Berlin, Heidelberg. ISBN 978-3-642-48318-9.

CHAUHAN, V. S. - SHARMA, A. 2003. Studies on organoleptic properties of food products from fresh egg and egg powder through principal component analysis. In Molecular Nutrition Food Research, vol. 47, no. 2, pp. 102-105.

KHATHIR, R. - AGUSTINA, R. - BASYIR, F. 2018. Study of the fermentation process in the processing of Pliek U. In Prosiding Seminar Nasional. Pembangunan Berbasis Kearifan Lokal (Local Wisdom). Banda Aceh, pp. 277-284. (In Indonesian: Kajian proses fermentasi pada proses pengolahan Pliek U).

KHATHIR, R. - AGUSTINA, R. - HARTUTI, S. - FAHMI, Z. 2020. Improving fermented virgin coconut oil quality by using microwave heating. In IOP Conference Series: Earth and Environmental Science, vol. 425.

LAWLESS, H. T. - HEYMANN, H. 2010. Sensory Evaluation of Food. In Springer New York Dordrecht Heidelberg London. ISBN 978-1-4419-6487-8.

MUSTAQIMAH - AGUSTINA, R. - FADHIL, R. - ZUHDI, I. - DEVIANTI. 2019. Study on physical characteristics of Pliek-U: comparisons among fermentation stages. In IOP Conference Series: Earth and Environmental Sciences, vol. 365.

PAPILO, P. - DJATNA, T. - ARKEMAN, Y. - MARIMIN. 2018. The application of fuzzy topsis in determining the location of the development area of the palm oil bioenergy supply chain. In Jurnal Agritech, vol. 38, no. 1, pp. 79-87. (In Indonesian: Penerapan fuzzy topsis dalam penentuan lokasi kawasan pengembangan rantai pasok bioenergy kelapa sawit). 
POCHAMPALLY, K. K. - GUPTA, S. M. - KAMARTHI, S. V. 2004. Evaluation of production facilities in a closed-loop supply chain a fuzzy topsis approach. In S. M. Gupta (Ed.). In Environmentally Conscious Manufacturing III, vol. 5262, pp. 125-138.

POPOV-RALJIC, J. V. - LALICIC-PETRONIJEVIC, J. G. 2009. Sensory properties and color measurements of dietary chocolates with different compositions during storage for up to 360 days. In Sensors, vol. 9, no. 3, pp. 1996-2016.

ROHAYA, S. - ERFIZA, N. M. - AMANDA, V. - SULAIMAN, I. 2019. Optimization of instant Pliek-U (fermented coconut meat) production using kinetic dryer. In IOP Conference Series: Materials Science and Engineering, vol. 536.

ROUHANI, S. - GHAZANFARI, M. - JAFARI, M. 2012. Evaluation mode of business intelligence for enterprise system using fuzzy TOPSIS. In Journal Expert System with Applications, vol. 39, pp. 3764-3771.

ROUYENDEGH, B. D. - YILDIZBASI, A. - YILMAZ, I. 2020. Evaluation of retail industry performance ability through integrated intuitionistic fuzzy TOPSIS and data envelopment analysis approach. In Soft Computing, vol. 24, pp. 12255-12266.

SHINDU, M. S. - RASHID, T. - KHASIF, A. 2019. Modeling of linear programming and extended TOPSIS in decision making problem under the framework of picture fuzzy sets. In Plos One, vol. 14, no. 8, pp. 1-13.

SIRANGELO, T. M. 2019. Sensory descriptive evaluation of food products: a review. In Journal of Food Science and Nutrition Research, vol. 2, no. 4, pp. 354-363.
TULKHAH, A. - SAIFUDDIN, A. 2019. Fuzzy topsis to improve the accuracy and objectivity of the weight in the vendor selection of PT.Telkomsel TTC BSD. In Jurnal Informatika Universitas Pamulang, vol. 4, no. 1, pp. 28-34. (In Indonesian: Fuzzy topsis untuk meningkatkan akurasi dan objektivitas bobot pada seleksi vendor PT. Telkomsel TTC BSD).

UMUDEE, I. - CHONGCHEAWCHAMNAN, M. - KIATWEERASAKUL, M. -TONGURAI, C. 2013. Sterilization of oil palm fresh fruit using microwave technique. In International Journal of Chemical Engineering and Applications, vol. 4, no. 3, pp. 111-113.

VIEIRA, T. M. F. S. - REGITANO-D'ARCE, M. A. B. 1998. Stability of oils heated by microwave: UV-spectrophotometric evaluation. In Journal of Food Science and Technology, vol. 18, no. 4, pp. 433.

YOON, K. 1980. System selection by multiple attribute decision making. Ph.D. Dissertation. Kansas State University, Manhattan, Kansas.

YOON, K. P. - KIM, W. K. 2017. The behavioral TOPSIS. In Expert Systems with Applications, vol. 89, pp. 266-272

YAZDI, M. - KORHAN, O. - DANESHVAR, S. 2020. Application of fuzzy fault tree analysis based on modified fuzzy AHP and fuzzy TOPSIS for fire and explosion in the process industry. In International Journal of Occupational Safety and Ergonomics, vol. 26, no. 2, pp. 319-335. 